\title{
Ecological background of the transboundary protected touristic territory in Western Altai
}

\author{
E. V. Selezneva, I. N. Rotanova \\ Altai State University, Barnaul, Russia. \\ E-mail: rotanova@mail.asu.ru
}

\section{Received 19.10.2019 Accepted 10.12.2019}

\begin{abstract}
Among the priority areas of international cooperation, environmental activities and the environmental imperative can be distinguished, which is directly reflected in the development of networks of specially protected natural areas (SPNA) of bordering countries, represented by various forms of organization of environmental institutions (biosphere reserves, nature reserves, national and natural parks, wildlife sanctuaries, etc.). International transboundary territories can often include objects of environmental protection and conservation of biological and landscape diversity of border regions, in particular, transboundary SPNA. The article deals with the organization of transboundary tourist areas in the Altai, including environmental institutions - transboundary conservation and tourist territories (TCTT). As an example, the transboundary biosphere reserve "Great Altai" on the basis of the State Natural Biosphere Reserve "Katunsky" (Russia, Altai Republic) and Katon-Karagay State National Natural Park (Kazakhstan, East-Kazakhstan region) is given. It is proposed to organize SPNA in the Russian-Kazakh border area of the Western Altai - Altai Krai (Russia) and East-Kazakhstan Region (Kazakhstan). Analyzed and evaluated the natural and tourist potential and protected areas of the region for the organization of SPNA in Western Altai.
\end{abstract}

Keywords: Tourism; Transboundary conservation and tourism territory; Protected areas; Altai; West Altai; Altai Krai; EastKazakhstan Region

\section{Introduction}

The development of international and domestic tourism in Russia necessitates the formation of the concept of new territorial touristrecreational systems (TTRS), as well as TTRS of new forms of spatial organization of tourist-recreational activities (Popova \& Podosenova, 2014). These include territorial conservation and tourism systems, or conservation and tourism territories, organized with the inclusion of protected natural areas in tourism activities (Rotanova, 2015a). In the tourism sector, the border territories of different states are becoming more actively involved, forming border and transboundary TTRS. They can be considered as one of the forms of organization of an international transboundary territory. According to (Prigranichnye..., 2011), an international transboundary territory is understood as a territory consisting of interacting border territories adjacent to the state border of two or more neighboring countries and possessing combinations of natural resources and various types of economic activity, with a single geosystem or a combination of two or more regional geosystems interacting in the state border zone being the natural basis. That is, the international transboundary territory is, most often, a complex geographical structure combining certain natural resources, infrastructure, population distribution, as well as its economic activities within the boundaries of a large geosystem. An important condition for the existence and effective development of an international transboundary territory is good neighborly relations between countries and mutually beneficial use of the potential of neighboring border territories (Prigranichnye..., 2011). Within the transboundary territories, in order to enhance inbound tourism, transboundary tourism territories are formed - territorial entities consisting of two or more neighboring or close to each other countries (or regions of these countries) that have a mutual desire to develop international tourism, the creation of a common tourism product and tourist exchange (Mirzekhanova, 2013). Transboundary tourism territories should be attributed to coherent (connected) regions, since their formation is based on relations focused on mutual interest in cooperation and development of tourism relations maintained at the state level (Rotanova, 2015a, 2015b; . Fedorov \& Korneevec, 2009). Among the priority areas of international cooperation, environmental activities and the environmental imperative can be distinguished, which is directly reflected in the development of networks of specially protected natural areas (SPNA) of bordering countries, represented by various forms of organization of environmental institutions (biosphere reserves, nature reserves, national and natural parks, wildlife sanctuaries, etc.). International transboundary territories can often include objects of environmental protection and conservation of biological and landscape diversity of border regions, in particular, transboundary SPNA (Prigranichnye..., 2011, Rotanova, 2015b). According to international approaches to transboundary protected areas, in particular, the concept of "continuous conservation" of biodiversity developed by the International Union for Conservation of Nature (IUCN) provides for the conservation of biological and landscape diversity "without borders", and environmental processes are considered not only within national and regional networks of protected areas, but also in adjacent territories (Rotanova \& Harlamova, 2014; Badenkov \& Rotanova, 2011). One example is the creation of the transboundary biosphere reserve The Greater Altai on the basis of the Katunsky State Nature, Biosphere Reserve (Russia) and Katon-Karagay State National Natural Park (Kazakhstan) (Jashina \& Krykbaeva, 2017). The reserve is located within the borders of the Altai Republic and the East Kazakhstan region and occupies areas intact by human activities, with an area of more than 1.5 million hectares. The reserve was created to 
preserve the natural complexes of protected areas of the Russian-Kazakhstan border. One of the strategies of the reserve is the development of regulated eco-cultural tourism in order to improve the well-being of local communities and contribute to raising awareness regarding the conservation of natural and cultural heritage. From the perspective of new forms of spatial organization of tourist and recreational activities, the transboundary biosphere reserve The Greater Altai should be considered as a transboundary conservation and tourism territory (TCTT), i.e., the territory of neighboring countries, which is adjacent to the state border, having certain combinations of natural resources, which are both conservation objects (SPNA) and objects of ecological and educational tourism interest.

\section{Material and Methods}

To assess the degree of value of the criterion for creating specially protected natural areas, the following gradation of ratings was used: high $(H)$ - 3 points; average $(A)-2$ points; low $(L)-1$ point; adverse (ADV) - 0 points (Table 1 ).

Table 1. Possibilities for organizing the conservation area of Western Altai.

\section{Criterion}

Representation

Uniqueness

Reference

Relicity and (or) endemism

\section{Size}

Presence of rare and (or) endangered species of flora or fauna

Presence of sites with the greatest species and landscape diversity

Socio-environmental relevance

Social order for recreational use of territories

\section{Brief Description}

Points

identifying the best or typical samples of different communities as specially protected, involves maintaining the full spectrum of community diversity across all gradients of conditions

uniqueness of a particular type of natural complex within larger physical and geographical units (zone, country, etc.)

presence in the territory of undisturbed or slightly modified natural complexes that could act as samples (standards) of the environment for the spaces adjacent to them refugia of the previously dominant plant community, a specific component of any flora, fauna. This criterion applies primarily to biotic components, but can be applied to the entire natural complex bearing the features of a relict element

territory size

has a biocentric connotation, but preservation of a rare component is impossible without maintaining a complex of conditions affecting it, therefore, the entire landscape, bearing rare features, should be protected

degree of diversity of the landscape structure is determined by the position of the territory in the system of physical-geographical zoning, biological diversity - by the ratio of the total number of all species to unit of area

criterion due to human economic activity; as a result of ongoing anthropogenic influences, natural complexes that were once typical of the region and requiring special protection in this regard may be lost; places of worship or religion, as well as sacred places and sources, are socially significant substantiation and organization of protected natural areas, in which, along with strictly protected areas, there would be places with regulated uses and regulated recreational load

\section{Results}

Prerequisites and possibilities for organizing TCTT using the experience of creating the transboundary biosphere reserve The Greater A/tai are in the Russian-Kazakhstan border area of Western Altai - Altai Krai and East Kazakhstan Region.

The planned TCTT of Western Altai is located in Altai Krai, in the Charysh river basin, including parts of the Kolyvan, Bashchelak, Korgon and Koksu ridges, as well as the Tigireksky ridge; in East Kazakhstan, TCTT occupies the right bank of the Irtysh River, including parts of the Ubinsky, Stanovoy, Chernovy ridges and Samanushinsky snow-covered peak.

Table 2. Evaluation of the possibility of organizing TCTT.

\section{Criterion}

\section{Representation}

Uniqueness

Reference

Relicity and (or) endemism

Size

Presence of rare and (or) endangered species of flora or fauna

Presence of sites with the greatest species and landscape diversity

Socio-environmental relevance

Social order for recreational use of territories

high $(\mathrm{H})$ - 3 points; average $(\mathrm{A})$ - 2 points; low $(\mathrm{L})$ - 1 point; adverse (ADV) - 0 points.

\section{Value*}

$\begin{array}{llll}\text { H } & \text { A } & \text { L } & \text { ADV } \\ + & - & - & - \\ + & - & - & - \\ + & - & - & - \\ + & - & - & - \\ + & - & - & - \\ + & - & - & - \\ + & - & - & - \\ - & + & - & - \\ + & - & - & -\end{array}$

TCTT of Western Altai will include SPNAs:

- From the Russian Federation (Altai Krai) - Tigireksky State Nature Reserve, the state nature reserves of regional significance 
Charyshsky, Bashchelaksky, Cascade of Waterfalls on the Shinok River, Chinetinsky, Tretyakovsky (planned);

- From the Republic of Kazakhstan (East Kazakhstan region) - West-Altai State Nature Reserve.

The transboundary protected and tourism area under development is characterized by the similarity of landscape diversity, a wide range of typical and unique natural complexes, which serves as the basis for joint environmental work of the two countries, as well as for the organization of eco-educational tourism, including transboundary one. Over 1700 species of plants grow there and over 260 species of animals inhabit the territory, many of which are listed in the Red Books of Altai Krai, the Russian Federation and the Republic of Kazakhstan. The Western Altai TCTT was evaluated from the point of view of environmental protection using the criteria for creating specially protected natural areas. The evaluation results are presented in Table 2. TCTT of Western Altai has a high environmental potential, which allows organizing transboundary environmental protection activities. An evaluation of the natural and tourism potential of the territory is given on the basis of the developed evaluation criteria (Table 3). To assess the degree of value of a natural resource, the following gradation of ratings was used: favorable (F) - 3 points; relatively favorable (RF) - 2 points; low favorable (LF) - 1 point; unfavorable (UNF) - 0 points, limiting factor minus 1.

Table 3. Evaluation of natural and tourism resources for TCTT of Western Altai.

\section{Criterion \\ Geomorphological resources}

Plant resources

Water resources

Glaciological resources

Recreational and hunting resources

Landscape diversity

Historical

attractions

Geological objects

Transport accessibility

Territory development

Recreational infrastructure

Avalanche hazard of the territory Degree of anthropogenic impact

\section{Brief Characteristics}

low-mountain, steep sided, moderately dissected, rocky (400-600 m) relief low-mountain, steep sided, strongly and moderately dissected $(400-800 \mathrm{~m})$ relief mid-mountain, steep sided, deeply dissected $(800-1000 \mathrm{~m})$ relief mid-mountain, steep sided, sharply dissected (1000-1500 m) relief alpine, peneplenized, deeply and sharply dissected, rocky-talus (1500-2000 m) relief alpine, alpinotypic, sharply and fractionally dissected with glaciers, rocky placers, snowfields (from $2000 \mathrm{~m}$ ) relief

meadow mixed grass steppes, in places shrubby, mixed grass steppe meadows deciduous forests combined with shrubbery and meadow steppes and meadows coniferous-forest and meadow-shrub vegetation

alpine and subalpine meadows and shrubs with areas of tundra and light forests moss-lichen, shrub tundra

presence of water bodies suitable for several types of recreational water use availability of water bodies suitable for certain types of recreational water use snow cover of 30-70 cm high lies from 3 to 6 months

hunting resources, low-mountain belt with small-leaved shrub-meadow vegetation, suitable for a wide range of recreational and hunting activities

areas with coniferous-deciduous and shrub-meadow vegetation suitable for a significant number of types of recreational and hunting activities

presence of unique and reference natural complexes, the change of various natural zones and altitudinal zonation

monuments of history and culture

archaeological sites and objects

rock deposits and outcrops

distance from regional centers of residence and services of the main places of recreation 30 - $300(400) \mathrm{km}$

territory with a developed network of rural settlements, mainly specialized in sectors of the agro-industrial sector presence of recreational facilities and services for seasonal functioning presence of single recreational institutions of temporary or seasonal functioning, tourist-climbing routes

low avalanche hazard; avalanche hazard coefficient is less than 0.25 territory of medium-altered landscapes (changes of 21-50\%)
Points

The evaluation results are presented in Table 4.

Table 4. Evaluation of natural and tourism resources.

\begin{tabular}{|c|c|c|c|c|c|}
\hline \multirow[t]{2}{*}{ Criterion } & \multicolumn{5}{|c|}{ Value } \\
\hline & $\mathbf{F}$ & $\mathbf{R F}$ & $\mathbf{L F}$ & UNF & LF \\
\hline Geomorphological resources & + & + & + & & \\
\hline Plant resources & + & + & & & \\
\hline Water resources & + & & & & \\
\hline Glaciological resources & & & + & & \\
\hline Recreational and hunting resources & + & + & & & \\
\hline Landscape diversity & + & & & & \\
\hline Historical sights & + & & & & \\
\hline Geological objects & + & & & & \\
\hline Transport accessibility & & & + & & \\
\hline Territory development & & + & & & \\
\hline Recreational infrastructure & & + & + & & \\
\hline Avalanche hazard of the territory & & & & & + \\
\hline Degree of anthropogenic impact & & + & & & \\
\hline
\end{tabular}




\section{Conclusion}

The obtained results of the evaluation of natural and tourism resources show that most of the presented criteria favor the development of ecological and educational tourism activities in the study area.

Within TCTT, the following activities are possible:

- Organization of monitoring, special scientific research in protected areas, as well as adjacent areas and the development of international and transboundary cooperation of protected areas;

- Sustainable use of the recreational and environmental-educational potential of protected areas and the territories adjacent to them;

- Development of educational tourism in the protected areas of transboundary regions.

The results of the geoecological evaluation allow us to conclude that there is a significant potential for the formation of a transboundary conservation and tourism territory of Western Altai.

\section{References}

Badenkov Ju. P., Rotanova I. N. (2011). Novye prirodoohrannye iniciativy i podhody v Altae-Sajanskom jekoregione. Polzunovskij vestnik, 4-2, 55-59 (in Russian).

Fedorov G. M., Korneevec V. S. (2009) Transgranichnye regiony v ierarhicheskoj sisteme regionov: sistemnyj podhod. Baltijskij region, 2, 32-42 (in Russian).

Jashina T. V., Krykbaeva R. N. (2017) Transgranichnyj biosfernyj rezervat «Bol'shoj Al-taj»: istorija sozdanija i strategii dejatel'nosti. Priroda, kul'tura i ustojchivoe raz-vitie Altajskogo transgranichnogo regiona. Proceed. Int. Sc. Conf. Gorno-Altajsk (in Russian).

Mirzehanova D. G. (2013). Formirovanie turisticheskogo produkta v predelah transgra-nichnyh territorij (na primere Habarovskogo kraja). Thesis of Doctoral Dissertation. Kaliningrad. Kant Baltic Federal University (in Russian).

Popova O. B., Podosenova I. A. (2014). Territorial'naja turistsko-rekreacionnaja sistema kak forma prostranstvennoj organizacii turistsko-rekreacionnoj dejatel'nosti. Nauka. Innovacii. Tehnologii. 3, 137-149 (in Russian).

Prigranichnye i transgranichnye territorii Aziatskoj Rossii i sopredel'nyh stran: (problemy i predposylki ustojchivogo razvitija) (2010). P.Ja. Baklanov, A.K. Tulohonov (Eds.). Novosibirsk: Siberian Branch Russian Academy of Science (in Russian).

Rotanova I. N (2015). Aktual'nost' i vozmozhnosti razvitija poznavatel'nogo turizma na prirodoohrannyh territorijah Altajskogo kraja. Nauka i turizm: strategii vzaimodej-stvija, 104-109 (in Russian).

Rotanova I. N. (2015). Vektory razvitija sfery turizma v prirodoohrannyh territorijah Altajskogo kraja v uslovijah stanovlenija rynka jekologicheskih uslug. Perehod k zelenoj jekonomike i ustojchivomu razvitiju v Altajskom krae: perspektivy, mehanizmy, kljuchevye napravlenija. Proceed. Int. Sc. Conf. Barnaul, Altai State Technical University (in Russian).

Rotanova I. N., Harlamova N. F. (2014) Rekreacionno-geograficheskie issledovanija v Altajskom regione. Barnaul: Altai State University (in Russian).

Selezneva E. V., Rotanova I. N. (2019) Ponjatie o transgranichnoj prirodoohranno-turisticheskoj territorii i vozmozhnosti ee organizacii v Zapadnom Altae. Prirodnye uslovija, istorija, kul'tura i jazyk Zapadnoj Mongolii i sopredel'nyh regionov. Proceed. XIV Int. Conf. Hovd, Hovd University, Sojombo Printing HHK-d hjevljev. 151-156 (in Russian).

\section{Citation:}

Selezneva, E. V., Rotanova, I. N. (2019). Ecological background of the transboundary protected touristic territory in Western Altai . Ukrainian Journal of Ecology, 9(4), 709-712.

(cc) $\mathrm{EY}$ This work is licensed under a Creative Commons Attribution 4.0. License 